

International Journal of Eurasia Social Sciences

Vol: 10, Issue: 37, pp. (899-915).

Research Article

Received: 10.04.2019 Accepted: 16.09.2019

\title{
PSYCHOMETRIC QUALITIES OF MEDICAL OUTCOMES STUDY SOCIAL SUPPORT SURVEY (MOS-SSS) IN TURKISH CULTURE
}

\author{
Tuğba YILMAZ \\ Dr. Öğr. Üyesi, İmir Bakırçay Üniversitesi, tugba.yilmaz.psy@gmail.com \\ ORCID: https://orcid.org/0000-0001-9187-7665 \\ Özlem BOZO \\ Profesör Doktor, Orta Doğu Teknik Üniversitesi, bozo@metu.edu.tr \\ ORCID: https://orcid.org/0000-0002-4480-1876
}

\begin{abstract}
The effect of social support has been investigated in numerous studies. Indeed, studies showed that social support is associated with health in many ways. As accepted, structural and functional support are distinct types of social support. The MOS Social Support Survey is an assessment tool that includes items measuring both types of social support. The MOS Social Support Survey was linguistically adapted to Turkish by translation and back-translation process. The study included a pre-test $(N=241)$ and a post-test $(N=99)$ conditions with one-month interval. The questionnaire set included a demographic information form, the MOS Social Support Survey, U.C.L.A. Loneliness Scale, Symptom Checklist 90-Revised, Multidimensional Scale of Perceived Social Support, and Inventory of Socially Supportive Behaviors. Factor analysis confirmed the fit of the 4-factor model. While the internal consistency reliability of the whole scale was .96, the test-retest reliability was .73 . The internal consistency reliabilities of the subscales ranged between .58 and 73. As an indicator for the divergent validity, the scale was negatively correlated with U.C.L.A Loneliness Scale $(r=-.65, p<.01)$ and SCL-90-Revised $(r=-.276, p<.01)$. For the convergent validity, the MOS Social Support Survey was correlated positively with MSPSS $(r=.657, p<.01)$ and ISSB $(r=.404, p<.01)$. The results of the study indicated that Turkish adaptation of the MOS Social Support Survey has satisfactory reliability and validity values..
\end{abstract}

Keywords: social support, psychology, reliability, validity, MOS Social Support Survey. 


\section{INTRODUCTION}

\section{Conceptualization of Social Support}

Social support has been conceptualized in different ways. First, structure of social support was investigated where structure refers to the presence and quantity of social interactions (Giangrasso \& Casale, 2014). To study this concept, researchers found ways to measure it. The first attempt was Berkman and Syme's (1979) social network index. They included four different types of structural social interactions and suggested that marital status, the number of relatives and friends, church participation, and participation in other organizations can be used to measure the social network. This type of measurement was also found to be related with several health behaviors, such as cancer screening behaviors (Suarez, Llyord, Weiss, Rainbolt, \& Pulley, 1994; Kang, Bloom, \& Romano, 1994; Seow, Huang, \& Straughan, 2000; Suarez et al., 2000).

However, other researchers claimed that the assessment of the social network is not able to assess social support properly since the large number of social ties does not necessitate high level of social interactions and social support or vice versa (Fleishman, Sherbourne, \& Crystal, 2000; Kahn \& Antonucci, 1980; Seeman \& Berkman, 1988; Sherbourne \& Stewart, 1991). Upon this discussion, Langford, Bowsher, Maloney, and Lillis (1997) suggested that the structure of social interaction is social network, whereas the function of this interaction refers to social support. They underlined the distinction between these two concepts by proposing that social network, and social embeddedness are the antecedents of social support.

Researchers also claimed that the availability of functional support, i.e., the extent to which relationships among people serve for functions, mainly refers to social support functions (Sherbourne \& Stewart, 1991; Uchino, Uno, \& Holt-Unstad, 1999; Seeman \& Berkman, 1988). As Giangrasso and Casale, (2014) pointed out, functional social support is the behavioral manifestation of social support given by other people in the social network. So, types of resources that are provided by social network means functional social support and a person can assess how available these kinds of resources to himself.

To measure functional social support researchers determined these functions. As a first step, House (1981) described five functions of social support, namely emotional support, instrumental support/tangible support, informational support, appraisal support, and social companionship. Sherbourne and Stewart (1991), however, suggested four dimensions of functional social support, namely emotional/ informational support, tangible support, affectionate support, and positive interactions in a study they conducted with chronically disturbed patients.

\section{Social Support and Health Behaviors}

Concerning social support and health behaviors relationship, several studies concluded different findings. First group of researchers supported that social support has direct effects of health behaviors. Uchino et al. (1999) suggested that social support promotes motivation for health behaviors. Similarly, Hernández et al. (2007) 
showed that social support has direct effects on the frequency of visits to doctor and self-medication. Second type of researchers suggested that social support has an indirect effect on health behaviors. For instance, DiMatteo (2004) indicated that social support can buffer the stress of being ill and decrease depression because it increases optimism and self-esteem. Likewise, Cohen and Wills (1985) suggested that social support indirectly protects people from negative effects of stressors and thereby leads people to become healthier. Bozo et al. (2014) showed the indirect effect of social support by suggesting that it is moderating the negative effects of type $C$ personality on quality of life of breast cancer patients.

Since social support affects health behaviors favorably, there has been an increase in the studies searching for the link between social support and health related issues, such as mortality (House, Landis, \& Umberson, 1988), maintaining healthy diet, adherence to medical routines and exercise (Jackson, 2006), diabetes (DiMatteo, 2004; Miller \& DiMatteo, 2013), and cancer screening (Andrade et al., 2005; Kang, Bloom, \& Romano, 1994; Katapodi, et al., 2002; Messina et al., 2004; Seow, Huang, \& Straughan, 2000; Straughan \& Seow, 2000; Suarez et al., 1994; Suarez et al., 2000).

To understand which dimension of social support is affecting health behaviors, researchers studied the effectiveness of its functions. Informational support may increase personal effectiveness in dealing with an overwhelming experience by providing guiding and recommendation (Helgeson \& Cohen, 1996). Emotional support means exchanging caring and concern in interpersonal relationships, thereby so it can decrease the stress a person goes through by the help of improving social interactions (Giangrasso \& Casale, 2014). Emotional support was found to be improve mental and physical health (Strine et al., 2008), and may reduce mortality (Reblin \& Uchino, 2009).

\section{Medical Outcomes Study Social Support Survey (MOS-SSS)}

Sherbourne and Stewart (1991) designed a social support survey to broaden the concept of social support. They developed a multidimensional social support survey including items to assess both structural and functional support. They stressed that perceived social support refers to a person's perception of the availability of different resources of social support. Medical Outcomes Study-social support survey (MOS-SSS) was originally developed and validated in the United States in English (1991). Since the items of the survey are short and can be understood easily, the survey was suggested to be appropriate for assessing social support of chronically ill patients. The scale is particularly advantageous since its items were further arranged to address the social needs of the chronically ill patients. The scale was a product of a large-scale health research project named the Medical Outcomes Research (the MOS).

MOS-SSS was adapted to several languages. It was also translated to Chinese with people living with HIV/AIDS (Yu et al., 2004), to Brazilian Portuguese with Hodgkin's lymphoma survivors (Soares, 2012), Chinese Mandarin with patients of coronary heart disease (Wang et al., 2013), and Malay with postpartum mothers (Norhayati et al., 2015). 
The survey was adapted to French Canadian (Anderson et al., 2005) with general population of students. Similarly, Giangrasso and Casale, (2014) validated Italian version of the scale with a general population of undergraduate students. Likewise, the main objective of the current study is to adapt the MOS-SSS to Turkish culture with a general population of undergraduate students and test the psychometric properties of the Turkish version of it.

\section{METHOD}

\section{Research Design}

This study was conducted with cross-sectional design. Respondents received questions via online platform and answered them. For test-retest reliability to be calculated, one month later respondents were reached again by e-mail and requested to fill out some questions.

\section{Participants}

A total of 241 Turkish university students (189 females and 52 males) were recruited for the Time 1 condition (mean age $=25.84, S D=5.437$, range $=18-60)$. They were selected with convenience sampling method. For the Time 2, out of 241 time 1 participants, 99 participants (41.08 \%, 71 females and 28 males) were volunteered to participate (mean age $=24.76, S D=4.52$, range $=19-42$ ). The demographic characteristics of the participants can be seen in Table 1.

Table 1. Demographic Characteristics of the Sample

\begin{tabular}{|c|c|c|c|c|}
\hline & \multicolumn{2}{|c|}{ Pre-test Group } & \multicolumn{2}{|c|}{ Post-test Group } \\
\hline & $N$ & $\%$ & $N$ & $\%$ \\
\hline \multicolumn{5}{|l|}{ Gender } \\
\hline Male & 52 & 21.6 & 28 & 28.3 \\
\hline Female & 189 & 78.4 & 71 & 71.1 \\
\hline \multicolumn{5}{|c|}{ Marital Status } \\
\hline Single & 103 & 42.7 & 47 & 47.5 \\
\hline Engaged & 102 & 42.3 & 37 & 37.4 \\
\hline Married & 36 & 15 & 15 & 15.2 \\
\hline \multicolumn{5}{|c|}{ Education Level } \\
\hline High school & 68 & 28.2 & 46 & 46.5 \\
\hline University & 110 & 45.6 & 33 & 33.3 \\
\hline Master's & 56 & 23.2 & 18 & 18.2 \\
\hline Doctorate & 7 & 2.9 & 2 & 2 \\
\hline
\end{tabular}

The participants who were present at Time 1 and who were present at Time 2 are compared on study variables. As independent samples $t$-test analysis suggested, these two groups were not significantly different in terms of received social support, perceived social support, loneliness, and psychopathology (see Table 2). 
Table 2. Descriptive Statistics and t-test Results for Time 1 and Time 2 Participants

\begin{tabular}{|c|c|c|c|c|c|c|}
\hline & & $n$ & $m$ & $s d$ & $t(239)$ & $p$ \\
\hline \multirow[t]{2}{*}{ UCLA } & Time 1 & 241 & 35.97 & 11.18 & .345 & \\
\hline & Time 2 & 99 & 35.45 & 11.47 & .345 & .73 \\
\hline \multirow[t]{2}{*}{ ISSB } & Time 1 & 241 & 104.33 & 31.56 & .099 & \\
\hline & Time 2 & 99 & 103.91 & 32.81 & .099 & .92 \\
\hline \multirow[t]{2}{*}{ MSPSS } & Time 1 & 241 & 66.65 & 15.39 & .662 & \\
\hline & Time 2 & 99 & 65.34 & 14.75 & .662 & .80 \\
\hline \multirow[t]{2}{*}{ SCL-90-R } & Time 1 & 241 & 163.72 & 48.18 & -.833 & \\
\hline & Time 2 & 99 & 169.38 & 56.98 & -.833 & .41 \\
\hline \multirow[t]{2}{*}{ MOS } & Time 1 & 241 & 78.50 & 13.04 & .248 & \\
\hline & Time 2 & 99 & 78.07 & 14.05 & .248 & .81 \\
\hline
\end{tabular}

Note. UCLA: University of California Los Angeles Loneliness Scale, ISSB: Inventory of Socially Supportive Behaviors, MSPSS: Multidimensional Scale of Perceived Social Support, SCL-90-R: Symptom Checklist 90 Revised, MOS: MOS Social Support Survey.

\section{Measures}

Demographic Information Form. This form included questions about gender, age, marital status, and education level. Moreover, participants were asked to give their e-mail addresses for the post-test condition.

MOS-SSS. The MOS-SSS was developed by Sherbourne and Stewart (1991). The first item of it assesses the number of the close relatives and friends (structural social support). The remaining 19 items of the test are answered on a 5-point Likert type scale ranging from 1 (none of the time) to 5 (all of the time). The test includes four subscales, namely emotional-informational support (8 items), positive interaction (3 items), affectionate support ( 4 items), and tangible support ( 3 items). The internal consistency reliability estimated by Cronbach's alpha was .97 for the total scale, .96, .94, .91, and .92 for emotional/informational support, positive interaction, affectionate support, and tangible support, respectively. The test-retest reliability with a 1-year interval was .78 for the total scale, .72, .72, .76, and .74 for emotional/informational support, positive interaction, affectionate support, and tangible support, respectively. The validity of the scale was tested by conducting Pearson Moment correlations between health status measures like physical health, mental health, both physical and mental health, and social support. The MOS-SSS had higher correlations with social support and lower correlations with physical health measures which indicated construct validity of the survey. Please see Appendix A for Turkish MOS-SSS.

University of California Los Angeles (UCLA) Loneliness Scale. UCLA Loneliness Scale was employed for testing divergent validity of MOS-SSS. The scale was developed by Russell, Peplau, and Ferguson (1978) and revised by Russell, Peplau, and Cutrona (1980). Turkish adaptation of the test was conducted by Demir (1989). This scale has 20 items and half of them were reversed. It is scored on a 4-point Likert type scale ranging between 1 (I never felt this way) and 4 (I often feel this way). Higher scores on this scale correspond to higher levels of loneliness. The reliability of the Turkish version was .96 and the test-retest reliability was conducted with a 5week interval was .94 (Demir, 1989). The correlations between UCLA Loneliness Scale, Beck Depression Inventory, and Social Introversion subscale of Multidimensional Depression Inventory were positive and 
significant (.77 and .82, respectively). Thus, the Turkish version of the scale was found as reliable and valid. In the current study, the internal consistency reliability of the scale was .93 .

Symptom Check List 90 Revised (SCL-90-R). SCL- 90-R is a self-administered inventory and it consists of 90 items, all of which are answered on a 5-point Likert scale ranging from 0 (never) to 4 (always). The inventory assesses the level of general psychopathological symptoms. Originally, the scale was developed by Derogatis (1977) and it was adapted to Turkish by Dağ (1991). It has 9 subscales, which are somatization, obsession and compulsion, interpersonal sensitivity, depression, anxiety, hostility, phobic anxiety, paranoid ideation, and psychoticism. The total score and the global severity index (GSI) were considered as measures of overall psychopathology. The internal consistency reliability of the test was .97. Test-retest reliability of GSI was .90 and it ranged for the subscales between .65 and .87. SCL-90-R and its all subscales were positively and significantly correlated with Beck Depression Inventory (Beck, Steer, \& Brown, 1996) and Minnesota Multiphasic Personality Inventory subscales except lie, masculinity-femininity, and hypomania (Butcher, Dahlstrom, Graham, Tellegen, \& Kaemmer, 1989). These findings suggested that SCL-90-R has satisfactory psychometric qualities in Turkish culture. In the present study, the internal consistency of the scale was .97.

Multidimensional Scale of Perceived Social Support (MSPSS). MSPSS consists of 12 items questioning the source and the level of social support provided by a significant other, family, and friends (Zimet et al., 1988). It is a 7-point Likert-type scale ranging from 1 (very strongly disagree) to 7 (very strongly agree). Higher scores on this scale indicate higher levels of social support perceived by respondents. The internal consistency reliability of the Turkish MSPSS ranged between .80 and .95 (Eker, Arkar, \& Yaldı, 2001). The correlation analyses between MSPSS, Beck Depression Inventory (Hisli, 1989), and State Trait Anxiety Inventory (Önder \& Le Compte, 1985) revealed that MSPSS is significantly and negatively correlated with BDI and State Trait Anxiety Scale, suggesting that MSPSS is a valid scale (Eker \& Arkar, 1995). In the present study, the internal consistency of the scale was found as .90 .

Inventory of Socially Supportive Behaviors (ISSB). ISSB is composed of 40 items and it measures the amount of the received social support. The scale was originally developed by Barrera et al. (1981) and adapted to Turkish by Erol and Bozo (2012). The scale has three subscales, guidance, emotional support, and tangible assistance. According to reliability analyses, Cronbach's alpha of the total inventory was.95 and the test-retest reliability was .69. For the subscales, guidance, emotional support, and tangible assistance test-retest reliability coefficients were $.95, .95$, and .81 , respectively. ISSB and its all subscales were positively and significantly correlated with MSPSS. In the current study, the internal consistency of the scale was .96.

\section{Procedure}

\section{Adaptation of MOS-SSS}

The MOS-SSS was linguistically adapted to Turkish by translation and back-translation process (Brislin et al., 1973). Three bilingual independent translators translated the original scale to Turkish. A bilingual psychologist 
who is competent both in English and Turkish decided on the best translated items that represented the original correspondents. After the comparison of the translated items with the original ones, the scale turned out to its final version.

\section{Ethical considerations}

After the study was approved by the Review Board of the Middle East Technical University, the questionnaire booklet was prepared and uploaded to an online data collection website (www.surveey.com) and the link for the study was delivered to the volunteer students enrolled to psychology classes. They were given extra credit for their participation. An inform consent form as well as a debriefing form were provided to all participants. The pre-test condition was completed with the online data gathering process. After a month, participants were contacted again by their e-mail addresses and they were requested to take the post-test survey. Ninety-nine out of 241 participants volunteered to take the test again.

\section{Data Analyses}

For time 1 measurement, MOS-SSS, UCLA Loneliness scale, SCL-90-R, MSPSS, and ISSB were administered to an initial of 241 participants. Exploratory factor analyses of 19 items of MOS- SSS were computed by SPSS (version 18.0) to understand the factor structure of it. The best resolution with the highest explained variance revealed the factor structure. For test-retest reliability, at time 2, ninety-nine participants (71 females and 28 males) filled out MOS-SSS, which was subjected to correlation analysis with time 1 MOS-SSS scores. Internal consistency reliability was computed with Chronbach's alpha. Construct validity of MOS-SSS was investigated by Person correlation with UCLA Loneliness scale, SCL-90-R, MSPSS, and ISSB at Time 1 measurements.

\section{FINDINGS (RESULTS)}

\section{Factor structure of Turkish MOS-SSS}

For the first step, 19 items of the MOS- SSS (answered on 5-point Likert type scale) measuring the level of functional support were analyzed by varimax rotation. Factor analysis revealed 3 factors with eigenvalues higher than 1 that were generated by using Kaiser Criteria. They explained $73.84 \%$ of the total variance. However, since the first factor included more than half of the items in the scale, which was not compatible with the original scale, factor analysis was tried with a 4-factor solution. Thereby, the item distribution of the Turkish MOS-SSS became comparable with the original one. The 4-factor solution explained more variance than the 3-factor solution ( $77.75 \%$ of the total variance). The item values, factor loadings, eigenvalues, and the explained variance of MOS- SSS can be seen in Table 3. 
Table 3. Factor Loadings for The MOS Social Support Survey

\begin{tabular}{|c|c|c|c|c|}
\hline Item & Factor 1 & Factor 2 & Factor 3 & Factor 4 \\
\hline 4. Someone to give you good advice about a crisis & .86 & .15 & .08 & .27 \\
\hline $\begin{array}{l}\text { 17. Someone to turn to for suggestions about how to deal } \\
\text { with a personal problem }\end{array}$ & .77 & .29 & .32 & .24 \\
\hline 13. Someone whose advice you really want & .75 & .24 & .32 & .24 \\
\hline $\begin{array}{l}\text { 3. Someone you can count on to listen to you when you } \\
\text { need to talk }\end{array}$ & .65 & .33 & .35 & .24 \\
\hline $\begin{array}{l}\text { 8. Someone to give you information to help you } \\
\text { understand a situation }\end{array}$ & .62 & .26 & .60 & .10 \\
\hline 19. Someone who understands your problems & .57 & .37 & .52 & .11 \\
\hline $\begin{array}{l}\text { 9. Someone to confide in or talk to about yourself or your } \\
\text { problems }\end{array}$ & .59 & .29 & .60 & .12 \\
\hline $\begin{array}{l}\text { 16. Someone to share your most private worries and fears } \\
\text { with }\end{array}$ & .52 & .25 & .60 & .22 \\
\hline $\begin{array}{l}\text { 14. Someone to do things with to help you get your mind off } \\
\text { the things }\end{array}$ & .88 & .06 & .20 & .26 \\
\hline 18. Someone to do something enjoyable with & .21 & .86 & .25 & .17 \\
\hline 11. Someone to get together for relaxation & .26 & .78 & .35 & .19 \\
\hline 7. Someone to have a good time with & .26 & .75 & .41 & .08 \\
\hline 6. Someone who shows you love and affection & .22 & .25 & .66 & .50 \\
\hline 20. Someone to love and make you feel wanted & .83 & .41 & .65 & .30 \\
\hline 10. Someone who hugs you & .29 & .27 & .64 & .39 \\
\hline 5. Someone to take you to the doctor if you needed it & .27 & .03 & .15 & .81 \\
\hline $\begin{array}{l}\text { 12. Someone to prepare your meals if you were unable to } \\
\text { do it yourself }\end{array}$ & .11 & .20 & .18 & .80 \\
\hline 2. Someone to help you if you were confined to bed & .18 & .07 & .08 & .77 \\
\hline 15. Someone to help with daily chores if you were sick & .14 & .27 & .25 & .74 \\
\hline Eigenvalue & 10.74 & 1.88 & 1.41 & .74 \\
\hline Explained variance (\%) & 56.20 & 9.88 & 7.43 & 3.92 \\
\hline Cronbach's $\alpha$ & .95 & .94 & .88 & .86 \\
\hline
\end{tabular}

Note. Factor 1: Emotional/Informational Support, Factor 2: Positive Interaction, Factor 3: Affectionate Support, Factor 4:

Tangible Support

The first factor, emotional/informational support, had a cutoff point of .52. It had 8 items and explained 56.52 $\%$ of the total variance. The second factor, positive interaction, had 4 items and it explained $9.88 \%$ of the total variance. The cutoff point of the second subscale was .75 . The third factor was named as affectionate support and it included 3 items. It explained $7.43 \%$ of the total variance, and its cutoff point was .64. The last factor was tangible support. It consisted of 4 items and explained $3.92 \%$ of the total variance. Its cutoff point was .74. According to the results of this factor analysis, it can be suggested that Turkish MOS-SSS has construct validity. The internal consistency reliability of the MOS-SSS estimated by Cronbach's alpha was found as .96 . Table 4 presents the summary of reliability analysis and Table 6 shows the factor structure and the internal consistency reliabilities of the subscales. 


\section{Reliability of Turkish MOS-SSS}

The test-retest reliability of the scale was examined by the re-application of the scale to 99 participants (41.08 \%) from the test group with one-month interval $(r=.727, p<.01)$. The test-retest reliability values for the subscales were as follows: emotional/ informational support $(r=.73, p<.001)$, positive interaction $(r=.65, p<$ $.001)$, affectionate support $(r=.67, p<0.001)$, and tangible support $(r=.58, p<.001)$.

\section{Validity of Turkish MOS-SSS}

MOS-SSS was correlated with UCLA Loneliness scale and SCL-90-Revised. MOS-SSS was negatively correlated with UCLA Loneliness Scale $(r=-.65, p<.01)$ and SCL-90-Revised $(r=-.276, p<.01)$. These results suggested that high functional support is associated with lower levels of loneliness and psychopathology.

Table 4. Reliability Analysis for The MOS Social Support Survey

\begin{tabular}{ccccc}
\hline Item Number & Item Mean & $S D$ & $\alpha$ if item deleted & Item-Total $r$ \\
\hline 2 & 4.28 & .84 & .956 & .48 \\
3 & 4.34 & .81 & .952 & .77 \\
4 & 4.26 & .87 & .953 & .68 \\
5 & 4.29 & .96 & .955 & .57 \\
6 & 4.34 & .84 & .952 & .78 \\
7 & 4.31 & .83 & .953 & .72 \\
8 & 4.12 & .94 & .952 & .79 \\
9 & 4.16 & .93 & .951 & .79 \\
10 & 4.11 & 1.09 & .952 & .76 \\
11 & 4.18 & .92 & .952 & .76 \\
12 & 4.02 & 1.04 & .955 & .57 \\
13 & 3.90 & 1.0 & .952 & .75 \\
14 & 4.04 & .93 & .953 & .65 \\
15 & 3.93 & 1.04 & .954 & .63 \\
16 & 3.67 & 1.23 & .952 & .78 \\
17 & 4.02 & .96 & .951 & .81 \\
18 & 4.17 & .88 & .953 & .70 \\
19 & 4.01 & .93 & .952 & .78 \\
20 & 4.17 & .95 & .952 & .79 \\
\hline Total scale & 78.33 & 13.43 & & \\
\hline
\end{tabular}

Note. Internal consistency reliability as calculated by Cronbach's $\alpha$ is .96 
Table 5. Reliability Analysis of the Subscales of the MOS Social Support Survey.

\begin{tabular}{|c|c|c|c|c|}
\hline Item Number & Mean & $S D$ & $\alpha$ if item deleted & Item-Total $r$ \\
\hline \multicolumn{5}{|c|}{ Emotional/Informational Support ${ }^{*}$} \\
\hline 4 & 4.26 & .87 & .94 & .74 \\
\hline 17 & 4.02 & .96 & .93 & .86 \\
\hline 13 & 3.90 & .99 & .94 & .79 \\
\hline 3 & 4.34 & .81 & .94 & .78 \\
\hline 8 & 4.12 & .94 & .93 & .85 \\
\hline 19 & 4.01 & .93 & .95 & .80 \\
\hline 9 & 4.16 & .94 & .93 & .84 \\
\hline 16 & 3.67 & 1.22 & .94 & .80 \\
\hline Total subscale & 32.49 & 6.58 & & \\
\hline \multicolumn{5}{|l|}{ Positive Interaction $^{* *}$} \\
\hline 14 & 4.04 & .93 & .92 & .84 \\
\hline 18 & 4.17 & .88 & .90 & .88 \\
\hline 11 & 4.18 & .92 & .91 & .85 \\
\hline 7 & 4.31 & .83 & .92 & .82 \\
\hline Total subscale & 10.55 & 3.25 & & \\
\hline \multicolumn{5}{|l|}{ Affectionate Support ${ }^{* * *}$} \\
\hline 6 & 4.34 & .84 & .81 & .79 \\
\hline 20 & 4.17 & .95 & .82 & .76 \\
\hline 10 & 4.11 & 1.1 & .85 & .74 \\
\hline Total subscale & 12.62 & 6.68 & & \\
\hline \multicolumn{5}{|l|}{ Tangible Support $^{* * * *}$} \\
\hline 5 & 4.29 & .96 & .81 & .71 \\
\hline 12 & 4.02 & 1.0 & .80 & .73 \\
\hline 2 & 4.28 & .84 & .84 & .63 \\
\hline 15 & 3.93 & 1.0 & .80 & .74 \\
\hline Total subscale & & 10.56 & & \\
\hline
\end{tabular}

Note. ${ }^{*}$ Internal consistency reliability as measured by Cronbach alpha is $.95,{ }^{* *}$ Internal consistency reliability as measured by Cronbach alpha is $.93,{ }^{* * *}$ Internal consistency reliability as measured by Cronbach alpha is $.88,^{* * * *}$ Internal consistency reliability as measured by Cronbach alpha is .86

MOS-SSS was correlated with MSPSS $(r=0.657, p<0.01)$ and ISSB $(r=0.404, p<0.01)$. In other words, higher scores on Turkish MOS-SSS was associated with higher perceived and received social support. These results suggested that Turkish MOS-SSS has satisfactory validity (see Table 5).

The validity analyses were repeated for the first question of MOS-SSS measuring structural support (the number of close relatives and friends). The results yielded that this single item was significantly and positively correlated with 19 items of the MOS-SSS $(r=.42, p<.01)$. Moreover, the number of close relatives and friends was significantly and negatively correlated with U.C.L.A Loneliness Scale $(r=-.48, p<.01)$ and SCL-90-Revised ( $r$ $=-.15, p<.05)$. Hence, large number of close relatives and friends was correlated with less loneliness and psychopathology. Similar to the original scale, it was also significantly and positively correlated with MSPSS ( $r=$ $.36, p<.01)$ and ISSB $(r=.16, p<.05)$. Higher structural support was positively correlated with functional 
support, perceived, and received social support. Table 6 presents correlation coefficients among the measures used in the current study.

Table 6. Correlation Coefficients of the Measures Used in Assessing Divergent and Convergent Validities

\begin{tabular}{ccccccc}
\hline & StSS & MOS & UCLA & MSPSS & SCL & ISSB \\
\hline StSS & --- & & & & & \\
MOS & $.42^{* *}$ & $(.95)$ & & & & \\
UCLA & $-.42^{* *}$ & $-.65^{* *}$ & $(.93)$ & & & \\
MSPSS & $.36^{* *}$ & $.66^{* *}$ & $-.71^{* *}$ & $(.91)$ & & \\
SCL & $-.15^{*}$ & $-.28^{* *}$ & $.48^{* *}$ & $-.36^{* *}$ & $(.97)$ & .03 \\
ISSB & $.16^{*}$ & $.40^{* *}$ & $-.28^{* *}$ & $.34^{* *}$ & $.03)$ \\
\hline
\end{tabular}

Note $1 .{ }^{*} p<.05, * * p<.01$

Note 2. StSS: Structural social support item, MOS: The MOS social support survey, UCLA: UCLA loneliness scale, MSPSS: Multidimensional scale of perceived social support, SCL: Symptom checklist 90 revised, ISSB: Inventory of socially supportive behaviors.

Note 3. Values in parentheses indicate the internal consistency reliability of the related scales

\section{CONCLUSION and DISCUSSION}

This study was conducted to adapt the MOS-SSS developed originally in English (Sherbourne \& Stewart, 1991) to Turkish culture and examine the psychometric properties of the adapted version. Results of the analyses indicated that the Turkish version of the MOS-SSS had satisfactory reliability and validity values.

The results of this study were largely consistent with the reliability and validity study of the original study (Sherbourne \& Stewart, 1991). The authors excluded the positive interaction item, item 14 (someone to do things with to help you get your mind off things), since it did not discriminate its subscale well. However, for the Turkish version of the scale, $14^{\text {th }}$ item was not excluded since in the factor analysis it loaded under the positive interaction subscale well (Table 4).

The other difference between the original scale and its Turkish version was related to the $1^{\text {st }}$ item of the scale. Sherbourne and Stewart (1991) found that this single item measuring structural support by questioning the number of close friends and relatives showed low correlations with functional support items. Hence, they argued that structural support was different from functional support, which was parallel to previous findings (Kahn \& Antonucci, 1980; Seeman, \& Berkman, 1988; Sherbourne \& Stewart, 1991; Fleishman, Sherbourne, \& Crystal, 2000). However, as it could be seen from Table 7, in our analysis this item correlated significantly with the remaining items of the MOS-SSS and with the other scales used to assess validity. It correlated positively with MOS-SSS items, MSPSS, and ISSB; and negatively with UCLA and SCL-90-R. Thus, the present findings can be supportive of the Langford et al.'s (1997) argument. These researchers proposed that social network is different from social support; it is an antecedent of social support. Having large number of close friends and relatives was related with less loneliness, less psychopathology, and with high received and perceived social support. Having large number of friends and relatives could mean having many alternative sources of social 
support, such as family, friends, relatives, neighbors, coworkers, the significant other, children, hospital staff, visitors etc.

The difference between the findings of the current study and the original study regarding the first item might be due to sample difference; Sherbourne and Stewart (1991) studied with chronic patients. Since chronic patients could be confined to hospitals or houses, they may have less available time for friends. Moreover, since they may focus more on themselves and the management of their conditions, their social network may shrink and thereby their structural social support decreases. In the present study, however, the sample was composed of general population of undergraduate students.

Age might be another reason of the difference between the findings of the original and current studies. In the original study the age range was 18-98 and the mean age was 55; however, in the current study the age range was $18-60$ and the mean age was 25.84 . This means that the average person in the original study was in his/her middle adulthood; however, the one in the current study was in his/her young adulthood. While young adulthood is characterized by increases in network through such as marriage and having a job; middle adulthood is closely related with shrinkage in network through such as retirement and divorce (Specht, Egloff, \& Schmugle, 2011). In addition, a person in the middle adulthood is expected to have established emotional and social development; however, an emerging adult is still developing emotional and social bonds, and thereby, the number of close friends and relatives tend to increase.

The average age difference between the studies might also explain loading of the item 14 (someone to do things with to help you get your mind off things) on the positive interaction subscale in the present study. An individual in his/her middle adult and having a chronic condition may lack an accompanier to get his mind off things but $s /$ he still may have positive interactions with people nearby. However, an emerging adult is more available to both having friends to get his mind off things and forming positive interactions with them.

The present study is not without its limitations. This study was conducted with non-clinical participants rather than patients with chronic conditions. Future studies are suggested to include participants with chronic conditions and make a comparison between disease-free participants and participants with chronic conditions in terms of functional and structural social support.

\section{SUGGESTIONS}

Due to its easy-to-read and short items, the MOS-SSS is a user-friendly instrument to assess social support of individuals with low educational level, inpatients, and patients with advanced chronic diseases. Health researchers, as well as psychologists working in health care facilities, could administer this survey to assess the level of structural and functional social support in Turkish patients. 


\title{
MEDIKAL SONUÇ ÇALIŞMASI SOSYAL DESTEK ÖLÇEĞI'NIN (MSÇ-SDÖ) TÜRK KÜLTÜRÜNDEKI PSIKOMETRIK ÖZELLIKLERININ INCELENMESi
}

\begin{abstract}
öz
Sosyal desteğin etkisi birçok çalışma tarafından incelenmiştir. Aslında, çalışmalar sosyal desteğin sağlıkla çeşitli şekillerde ilişkili olduğunu göstermektedir. Genel olarak kabul edildiği üzere sosyal desteğin yapısal ve işlevsel olmak üzere iki farklı türü bulunmaktadır. Medikal Sonuç ÇalışmasıSosyal Destek Ölçeği (MSÇ-SDÖ) iki tür sosyal desteği de ölçen maddeleri içeren bir değerlendirme aracıdır. Çeviri ve tekrar-çeviri yöntemi ile MSÇ-SDÖ Türkçe'ye çevrilmiştir. Çalışmanın bir ay arayla gerçekleştirilen ön-test $(N=241)$ ve son-test $(N=99)$ aşamaları vardır. Kullanılan ölçekler U.C.L.A. Yalnızlık Ölçeği, Belirti Tarama Testi, Çokboyutlu Sosyal Destek Ölçeği ve Sosyal Destek Davranışları Ölçeği'dir. Faktör analizi 4 faktör modelin uygunluğunu doğrulamıştır. Tüm ölçeğin iç tutarlığı .96 iken, test tekrar-test güvenirliği .73'tür. Ayrışan geçerlik için tüm ölçek U.C.L.A. Yalnızlık Ölçeği $(r=-.65, p<.01)$ ve Belirti Tarama Testi ile $(r=-.276, p<$ .01) negative korelasyon göstermiştir. Birleşen geçerlik için ise tüm ölçek Çokboyutlu Sosyal Destek Ölçeği $(r=.657, p<.01)$ ve Sosyal Destek Davranışları Ölçeği $(r=.404, p<.01)$ ile pozitif korelasyon göstermiştir. Bulgular MSÇ-SDÖ’nün Türkçe uyarlamasının yeterli psikometrik özelliğinin olduğunu göstermektedir.
\end{abstract}

Anahtar kelimeler: sosyal destek, psikoloji, gerçelik, güvenirlik, MSÇ sosyal destek ölçeği 


\section{REFERENCES}

Anderson, D., Bilodeau, B., Deshaies, G., Gilbert, M., \& Jobin, J. (2005). French Canadian validation of the MOS social support survey. Canadian Journal of Cardiology, 21(10), 861-873.

Andrade, C. R., Chor, D., Faerstein, E., Griep, R.H., Lopes, C. S., \& Fonseca, M. J. M. (2005). Social support and breast self-examination in the Pró-Saúde study. Reports in Public Health, 21(2), 379-386.

Barrera, M. (1986). Distinction between social support concepts, measures and models. American Journal of Community Psychology, 14(4), 413-445.

Beck, A. T., Steer, R. A., \& Brown, G. K. (1996). Manual for the Beck Depression Inventory (2 ${ }^{\text {nd }}$ ed). San Antonio TX: Psychological Corporation.

Berkman, L. F., \& Syme, S. L. (1979). Social networks, host resistance and mortality: a nine year follow up study of Alameda Country residents. American Journal of Epidemiology, 109, 186-204.

Brislin, R. W., Lonner, W. J., \& Thorndike, R. M. (1973). Cross-Cultural Research Methods. New York, Wiley.

Butcher, J. N., Dahlstrom, W. G., Graham, J. R., Tellegen, A., \& Kaemmer, B. (1989). The Minnesota Multiphasic Personality Inventory-2 (MMPI-2): Manual for administration and scoring. Minneapolis MN: University of Minnesota Press.

Bozo, Ö., Tathan, E., \& Yılmaz, T. (2014). Does perceived social support buffer the negative effects of type c personality on quality of life of breast cancer patients? Social Indicators Research, 119(2), 791-801.

Cohen, S., \& Wills, T. A. (1985). Stress, social support and the buffering hypothesis, Psychological Bulletin, 98, 310-357.

Dağ, İ. (1991). Symptom checklist (SCL-90-R): A reliability and validity study. Turkish Journal of Psychiatry, 2(1), 5-12.

Demir, A. (1989). Reliability and validity of U.C.L.A. Ioneliness scale. Turkish Journal of Psychology, 7(23), 14-18.

Derogatis, L. R. (1977). SCL-90: Administration, scoring and procedure manual I for the revised version.

Baltimore MD: John Hopkins University School of Medicine, Clinical Psychometrics Unit.

DiMatteo, M. R. (2004). Social support and patient adherence to medical treatment: A meta-analysis. Health Psychology, 23, 207-218.

Eker, D., \& Arkar, H. (1995). Perceived social support: Psychometric properties of the MSPSS in normal and pathological groups in a developing country. Social Psychiatry and Psychiatric Epidemiology, 30, 121126.

Eker, D., Arkar, H., \& Yaldız, H. (2001). The factor structure, reliability, and validity of revised multidimensional perceived social support scale. Turkish Journal of Psychiatry, 12(1), 17-25.

Erol, R. Y., \& Bozo, Ö. (2012). Adaptation, reliability and validity study of the Inventory of Socially Supportive Behaviors. Anatolian Journal of Psychiatry, 13, 210-215.

Fleishman, J. A., Sherbourne, C. D., \& Crystal, S. (2000). Coping, conflictual social interactions, social support, and mood among HI- infected persons. American Journal of Community Psychology, 28, 421-453.

Giangrasso, B., \& Casale, S. (2014). Psychometric properties of medical outcomes study social support survey with a general population sample of undergraduate students. Social Indicators Research, 116, 185-197. 
Hernández, S. O., Parga, M. X. F., \& Azgar, C. M. (2007). Illness behavior: Prediction by symptoms, the Grossarth-Maticek and Eysenck personality types, neuroticism, life events, coping, health locus of control, social support, and attribution style. The Spanish Journal of Psychology, 10(2), 388-398.

Helgeson, V. S., \& Cohen, S. (1996). Social support and adjustment to cancer: Reconciling descriptive, correlational, and intervention research. Health Psychology, 15(2), 135-148

Hisli, N. (1989). Validity and reliability study of Beck Depression Inventory for university students. Turkish Journal of Psychology, 23(7), 3-13.

House, J. S., Landis, K. R., \& Umberson, D. (1988). Social relationships and health. Science, 241, 540-545.

Jackson, T. (2006). Relationships between perceived close social support and health practices within community samples of American women and men. The Journal of Psychology, 140(3), 229-246.

Kahn, R. L., \& Antonucci T. C. (1980). Convoys over the life course: Attachment, roles and social support. In P. B. Baltes and O.Brim (Eds). Life Span Development and Behavior(pp. 253-286). New York, NY: Academic Press.

Kang, S. H., Bloom, J. R., \& Romano, P. S. (1994). Cancer screening among African-American women: their use of tests and social support. American Journal of Public Health, 8(1), 101-103.

Katapodi, M. C., Facione, N. C., Miaskowski, C., Dodd, M. J., \& Waters, C. (2002). The influence of social support on breast cancer screening in a multicultural community sample. Oncology Nursing Forum, 29(5), 845852.

Langford, C. P. H., Bowsher, J., Maloney, J. P., \& Lillis, P. P. (1997). Social support: a conceptual analysis. Journal of Advanced Nursing, 25, 95-100.

Messina, C. R., Lane, D. S.,West, D. S., Frishman, W., Glanz, K., Taylor, W., \& Powell, L. (2004). Relationship of social support and social burden to repeated breast cancer screening in the women's health initiative. Health Psychology, 23(6), 582-594.

Miller, T. A., \& DiMatteo, M. R. (2013). Importance of family/social support and impact adherence to diabetic therapy. Diabetes, Metabolic Syndrome and Obesity: Targets and Therapy, 6, 421-426..

Norhayati, M. N., Aniza, A. A., Hazlina, N. H. N., \& Azman, M. Y. (2015). Psychometric properties of the revised malay version medical outcome study social support survey using confirmatory factor analysis among postpartum mothers. Asia-Pacific Psychiatry, 7(4), 398-405.

Önder, N., \& Le Compte, A. (1985). Durumluk-Sürekli Kaygı Envanteri El Kitabı (íkinci baskı) [Handbook of StateTrait Anxiety Inventory]. Istanbul: Boğaziçi Press.

Reblin, M., \& Uchino, B. N. (2009). Social and emotional support and its implication for health. Current Opinions in Psychiatry, 21(2), 201-205.

Russell, D., Peplau, L. A., \& Ferguson, M. L. (1978). Developing a measure of loneliness. Journal of Personality Assessment, 42, 290-294.

Seeman, T, E., \& Berkman, L. F. (1988). Structural characteristics of social networks and their relationship with social support in the elderly: who provides support? Social Science \& Medicine, 26, 737-749. 
Seow, A., Huang, J., \& Straughan, P. T. (2000). Effects of social support, regular physician and health related attitudes on cervical cancer screening in an Asian population. Cancer Causes and Control, 11, 223-230.

Sherbourne, C. D., \& Steward, A. L. (1991). The MOS social support survey. Social Science \& Medicine, 32(6), 705-714.

Soares, A., Biasoli, I, Scheliga, A., Baptista, R. L., Brabo, E. P., Morais, J. C.,...Spector, N. (2012). Supportive Care in Cancer, 20(8), 1895-1900.

Specht, J., Egloff, B., \& Schmugle, S. C. (2011). Stability and change in personality across the lifecourse: The impact of age and major life events on mean-level and rank-order stability of the Big-Five. Journal of Personality and Social Psychology, 101, 862-882.

Straughan, P. T., \& Seow, A. (2000). Attitudes as barriers in breast screening: a prospective study among Singapore women. Social Science \& Medicine, 51, 1695-1703.

Strine, T. W., Chapman, D. P., Balluz, L., \& Mokdad, A. H. (2008). Health related quality of life and health behaviors by emotional and social support. Their relevance of psychiatry and medicine. Social Psychiatry and Psychiatric Epidemiology, 43(2), 151-159.

Suarez, L., Llyord, L., Weiss, N., Rainbolt, T., \& Pulley, L. (1994). Effect on social networks on cancer screening behavior of older Mexican American women. Journal of National Cancer Institute, 86(10), 775-779.

Suarez, L., Ramirez, A. G., Villarreal, R., Marti, J., McAlister, A., Talavera, G. A., Trapido, E., \& Perez-Stable, E. J. (2000). Social networks and cancer screening in four US hispanic groups. American Journal of Preventive Medicine, 19(1), 47-52.

Wang, W., Zheng, X., He, H-G, Thompson, D. R. (2013). Psychometric testing of the chinese mandarin version of the medical outcomes study social support survey in patients with coronary heart disease in mainland china. Quality of Life Research, 22(8), 1965-1971.

Uchino, B. N., Uno, D., \& Holt-Unstad, J. (1999). Social support, physiological processes, and health. Current Directions in Psychological Science, 8(5), 145-148.

Yu, D. S. F., Lee, D. T. F., \& Woo, J. (2004). Psychometric testing of the Chinese version of the medical outcomes study social support survey (MOS-SSS-C). Research in Nursing \& Health, 27, 135-143.

Zimet, G. D., Dahlem, N. W., Zimet, S. G., \& Farley, G. K. (1988). The Multidimensional Scale of Perceived Social Support. Journal of Personality Assessment, 52, 30-41. 


\section{APPENDIX A. TURKISH MOS-SSS}

Aşağıda size verilebilecek destekler ile ilgili sorular yer almaktadır.

1.Yaklaşık olarak kaç tane (yanındayken rahat hissettiğiniz ve aklınızdan geçenleri konuşabildiğiniz) yakın arkadaşınız ve yakın akrabanız vardır?

Yakın arkadaş ve yakın akrabalarınızın sayısını yazınız:

Bazen diğer insanların yanımızda olmasını, bize arkadaşlık etmesini ya da başka şekillerde bize destek olmasını isteriz. İhtiyacınız olduğunda aşağıdaki destek türlerini ne sıklıkla alabileceğinizi düşünüyorsunuz?

Her satırdan bir numarayı daire içine alınız.

\begin{tabular}{|c|c|c|c|c|c|}
\hline & $\begin{array}{l}\text { Hiçbir } \\
\text { zaman }\end{array}$ & Nadiren & Bazen & Çoğunlukla & $\begin{array}{c}\text { Her } \\
\text { zaman }\end{array}$ \\
\hline 2. Yatağa düştüğünüzde size yardım edecek birisi & 1 & 2 & 3 & 4 & 5 \\
\hline $\begin{array}{l}\text { 3. Konuşmaya ihtiyacınız olduğunda sizi } \\
\text { dinleyeceğine güveneceğiniz birisi }\end{array}$ & 1 & 2 & 3 & 4 & 5 \\
\hline $\begin{array}{l}\text { 4. Bir sorunla karşılaştığınızda size tavsiye } \\
\text { verecek birisi }\end{array}$ & 1 & 2 & 3 & 4 & 5 \\
\hline $\begin{array}{l}\text { 5. İhtiyaç duyduğunuzda sizi doktora götürecek } \\
\text { birisi }\end{array}$ & 1 & 2 & 3 & 4 & 5 \\
\hline 6. Size sevgi ve şefkat gösteren birisi & 1 & 2 & 3 & 4 & 5 \\
\hline 7. Birlikte iyi vakit geçireceğiniz birisi & 1 & 2 & 3 & 4 & 5 \\
\hline $\begin{array}{l}\text { 8. Kendiniz ya da problemleriniz hakkında } \\
\text { konuşabileceğiniz ya da sır verebileceğini birisi }\end{array}$ & 1 & 2 & 3 & 4 & 5 \\
\hline $\begin{array}{l}\text { 9. Güvenip içinizi dökebileceğiniz ya da } \\
\text { kendinizden veya sorunlarınızdan } \\
\text { bahsedebileceğiniz birisi }\end{array}$ & 1 & 2 & 3 & 4 & 5 \\
\hline 10. Size sarılacak birisi & 1 & 2 & 3 & 4 & 5 \\
\hline $\begin{array}{l}\text { 11. Rahatlamak için bir araya gelebileceğiniz } \\
\text { birisi }\end{array}$ & 1 & 2 & 3 & 4 & 5 \\
\hline $\begin{array}{l}\text { 12. Kendiniz yapamayacak durumda iken size } \\
\text { yemek hazırlayacak birisi }\end{array}$ & 1 & 2 & 3 & 4 & 5 \\
\hline $\begin{array}{l}\text { 13. Tavsiyesine gerçekten ihtiyaç duyduğunuz } \\
\text { birisi }\end{array}$ & 1 & 2 & 3 & 4 & 5 \\
\hline $\begin{array}{l}\text { 14. Kafanızı dağıtmak için bir şeyler yapacağınız } \\
\text { birisi }\end{array}$ & 1 & 2 & 3 & 4 & 5 \\
\hline $\begin{array}{l}\text { 15. Hasta olduğunuzda günlük işlerinizde yardım } \\
\text { edecek birisi }\end{array}$ & 1 & 2 & 3 & 4 & 5 \\
\hline $\begin{array}{l}\text { 16. En mahrem/kişisel endişe ve } \\
\text { korkularınızıpaylaşacağınız birisi }\end{array}$ & 1 & 2 & 3 & 4 & 5 \\
\hline $\begin{array}{l}\text { 17. Başvurduğunuzda, kişisel bir probleminizi } \\
\text { çözmek için önerilerde bulunacak birisi }\end{array}$ & 1 & 2 & 3 & 4 & 5 \\
\hline 18. Birlikte eğlenceli bir şeyler yapacağınız birisi & 1 & 2 & 3 & 4 & 5 \\
\hline 19. Sorunlarınızı anlayan birisi & 1 & 2 & 3 & 4 & 5 \\
\hline $\begin{array}{l}\text { 20. Kendinizi değerli hissettirecek ve sizi sevecek } \\
\text { birisi }\end{array}$ & 1 & 2 & 3 & 4 & 5 \\
\hline
\end{tabular}

